\title{
THE HOPE OF WOMEN WITH HIV/AIDS: EVALUATION USING THE HERTH SCALE
}

\author{
Fabiana de Souza Orlandi ${ }^{1}$, Neide de Souza Praça ${ }^{2}$
}

\begin{abstract}
${ }^{1}$ Ph.D. in Sciences. Adjunct Professor of the Department of Gerontology at Federal University of São Carlos. São Paulo, Brazil. E-mail: forlandi@ufscar.br

${ }^{2}$ Ph.D. in Nursing. Associate Professor of the Department of Maternal-Child and Psychiatric Nursing at University of São Paulo School of Nursing. São Paulo, Brazil. E-mail: ndspraca@usp.br
\end{abstract}

\begin{abstract}
This descriptive cross-sectional study had the objective to evaluate the level of hope in women aged 50 or older suffering from HIV / AIDS, utilizing the Herth Hope Scale. The study involved $200 \mathrm{HIV}$ - positive women, within the age bracket of interest, enrolled in three STI/AIDS specialized healthcare services in the city of São Paulo. The rules of the 196/96 Resolution were met and the study was approved by the Research and Ethics Committee. Data were collected in 2010 using two instruments: subjects' characterization and the Herth Hope Scale. Results demonstrated an average score of $36.75( \pm 4.52)$ on the Herth Hope Scale, with an interval of 12 to 48 . This score is below the score obtained with the same scale for various pathologies, indicating a reduced perception of hope by the sample. Nurses should provide interventions to improve hope for these people, establishing realistic goals and strengthening social support. DESCRIPTORS: Women's health. HIV. Acquired Immune Deficiency Syndrome. Life expectancy. Aging.
\end{abstract}

\section{A ESPERANÇA NA VIDA DE MULHERES COM HIV/AIDS: AVALIAÇÃO PELA ESCALA DE HERTH}

RESUMO: Este estudo descritivo, transversal, teve como objetivo avaliar o nível de esperança de mulheres com 50 anos ou mais, com HIV/aids, pela Escala de Esperança de Herth. Foram entrevistadas 200 mulheres soropositivas na faixa etária de interesse, matriculadas em três Serviços de Assistência Especializada em DST/aids do município de São Paulo. Foi atendida a Resolução 196/96 e o estudo foi aprovado por Comitê de Ética em Pesquisa. Os dados foram coletados em 2010 com preenchimento de dois instrumentos: caracterização dos sujeitos e Escala de Esperança de Herth. Os resultados mostraram escore médio na aplicação da Escala de Esperança de Herth de $36,75( \pm 4,52)$, num intervalo de 12 a48. Este escore está abaixo dos obtidos com a mesma escala para diversas patologias, indicando reduzida percepção de esperança de vida pela amostra. O enfermeiro deve propor suas ações na busca da melhoria da esperança da pessoa assistida, estabelecendo metas realistas e fortalecendo o suporte social.

DESCRITORES: Saúde da mulher. HIV. Síndrome da imunodeficiência adquirida. Esperança de vida. Envelhecimento.

\section{LA ESPERANZA EN LA VIDA DE MUJERES CON VIH/SIDA: EVALUACIÓN POR LA ESCALA DE HERTH}

\begin{abstract}
RESUMEN: Estúdio transversal-descriptivo que tuvo como objetivo evaluar el nível de esperanza de vida para las mujeres mayores de 50 años com VIH/SIDA por la Escala de Esperanza de Herth. Se entrevistaron a 200 mujeres VIH-positivas en el grupo de edad de interés, asistidas en tres Servicios de Atención Especializada de ETS/SIDA en São Paulo. Se cumplió la Resolución 196/96 y el estudio fue aprobado por el Comité de Ética en Investigación. Los datos fueron recolectados en el año 2010 con la aplicación de dos instrumentos: caracterización de los sujetos y Escala de Esperanza de Herth. Los resultados mostraron una puntuación media de la aplicación de la Escala de Esperanza de Herth de $36.75( \pm 4,52)$, dentro de los 12 a 48. Esta puntuación está por debajo de los obtenidos con la misma escala para diversas patologías, lo que indica la percepción de la esperanza de vida reducida por la muestra. El enfermero debe proponer acciones que busquen la mejoría de la esperanza de la persona asistida, estableciendo metas realistas y fortaleciendo el suporte social. DESCRIPTORES: Salud de la mujer. VIH. Síndrome de inmunodeficiencia adquirida. Esperanza de vida. Envejecimiento.
\end{abstract}




\section{INTRODUCTION}

HIV infection in women deserves special attention, mainly due to its increasing incidence in the past few years, inequalities regarding socio-economic, cultural and gender contexts, and changes in the carriers' epidemiologic profiles. ${ }^{1-2}$

Epidemiological data published by the health manager reveal the number of cases reported to the Notifiable Diseases Reporting Information System (SINAN in Brazilian acronyms) according to gender. In 2011, 9,035 cases of AIDS were reported in males, while 5,491 cases of AIDS were reported in women, comprising all age brackets. When compared to the period spanning 1980 to $1997,123,714$ cases were reported in males and 39,125 in women. Therefore, we can observe a crescent incidence of cases in women and a decrease in the women/men ratio. Among women, $10.1 \%$ of cases occur in women aged 50 years or older. Infection with the HIV in the population over 50 years old has increased in Brazil more than in any other age group, and this growth is greatest among women.

Scientific progress brought about by highpowered antiretroviral therapy has raised life expectancy in HIV/AIDS carriers, turning them into carriers of a potentially controllable chronic disease. $^{4}$

Every chronic disease impacts individuals' lives, both in the personal and professional realms. Living with a chronic disease requires the ability to deal with complex therapeutic regimes and the need for alterations in activities of daily living, which may lead to feelings of hopelessness. ${ }^{5}$

Maintaining hope when dealing with a chronic disease is an endless process; however, hope is a valuable resource in dealing with this condition. ${ }^{5}$ Hope is one of the central aspects of nursing care. ${ }^{6}$ Hope has a beneficial effect on the health of people, contributing to their ability to deal with crisis situations in order to maintain quality of life, determining healthy goals and promoting health. ${ }^{7}$ The evaluation of hope allows the implementation of interventions that will aid people with chronic diseases and their families. ${ }^{8}$ This is a subsidy that will enable planning of interventions with a view to reducing the impact of disease on individuals' daily life. ${ }^{9}$

In addition, the literature demonstrates a lack of research evaluating the level of hope in HIV-positive women within the Brazilian context.
This present study had the objective of evaluating the level of hope in women aged 50 years or older, carriers of HIV/AIDS, using the Herth Hope Scale; these women are featured according to sociodemographic and clinical aspects.

\section{METHOD}

This study is a descriptive cross-sectional research performed in three STI/ AIDS specialized healthcare services (SAE in Brazilian acronyms) in the city of São Paulo, one in the north region and the other two in the east region of the city. STI/ AIDSSAEs are specialized health services offering preventive, diagnostic and treatment interventions for people with STI/HIV/AIDS. They work as a clinical service with a multiprofessional team.

Calculation of the sample size considered the following: the coefficient value of the correlation (Pearson) $r \geq 0.20$ and the fixed values for $\alpha=0.05$ and $\beta=0.20{ }^{10}$ Thus, the sample size was defined as 194 subjects; however, 200 women provided data for collection.

The sample was comprised of 200 women who met the following inclusion criteria: aged 50 years or older; being a carrier of HIV/AIDS (regardless of the infection stage) and being an out-patient of one of the Specialized Health Care Services clinics in this study. Data collection occurred when the women who met the inclusion criteria came for their medical appointments and were invited to participate in the study. Clinical data were extracted directly from their medical files. They answered two instruments during individual interviews, performed in a private room within the outpatient clinics, before or after their medical appointment.

Of the two instruments employed in the interview, one of them specifically characterizes the population aged 50 years or older who are carriers of HIV/AIDS. The instrument was built and validated for the Brazilian context ${ }^{11}$ and is comprised of sociodemographic questions (marital status, religion, age, education, profession, occupation, income) and medical questions (viral load, CD4 count, HIV infection stage, presence of opportunistic diseases related to HIV/ AIDS or other pathologies, use of antiretroviral and/or nonantiretroviral medications). Moreover, habit and behavior questions are included (tobacco, alcohol and drug use), questions regarding sexuality (relationship and sexual partners, marital situation, number of partners, use of condoms, justification 
for non-compliance with the use of condoms), and beliefs and actions related to the disease and the treatment (time since diagnosis and how they became aware of the diagnosis, beliefs about the mode of infection, complications resulting from the infection, time of treatment, perceptions of therapeutic advantages and treatment dropout).

In addition to the instrument mentioned above, the Herth Hope Index Scale was adopted, which has been validated in Brazil (HHS). It is a self-reporting scale from the USA ${ }^{9}$ which quantifies life expectancy. The scale comprises twelve affirmations and items gradation follows the four-point Likert-type scale, varying from "totally agree" to "totally disagree", where 1 indicates "totally disagree" and 4 indicates "totally agree". Items 3 and 6 present inverted scores. Total score varies from 12 to 48 and the higher the score, the higher the level of hope. It is considered to be a brief and easily understood scale.

Data were coded and organized into a data base with double entries and value comparisons using the Microsoft Excel 2000 software. Data treatment was performed using the Statistics Software SPSS (Statistical Package for the Social Science) 16.0 for Windows. Data were subjected to descriptive analysis. Hence, position (mean, median, minimum and maximum) and dispersion (standard deviation) measures were calculated. Reliability in the HHS was tested using Cronbach's Alpha (a) internal consistency test. A value of 0.7 was adopted as the inferior limit of internal consistency. ${ }^{13}$

This study was approved by the Research Ethics Committee of the Municipal Secretary of Health of São Paulo, under protocol number 09/2010.

\section{RESULTS}

Data were collected throughout the period of March to July of 2010, and are presented in subcategories: characterization and medical condition of the sample, and hope.

\section{Characterization and medical condition}

To characterize the subjects in the sample and their medical condition, tables 1 to 3 are presented as follows.

Table 1 - Sociodemographic characterization of the subjects in the sample. São Paulo, 2010 $(n=200)$

\begin{tabular}{llrr}
\hline Variables & Categories & $\mathbf{n}$ & \multicolumn{1}{c}{$\%$} \\
\hline \multirow{3}{*}{ Age } & 50 to 59 years & 146 & 73.0 \\
& 60 to 69 years & 44 & 22.0 \\
Marital status & 70 years or more & 10 & 5.0 \\
& With a partner & 48 & 24.0 \\
& No partner & 152 & 76.0 \\
& Catholic & 96 & 48.0 \\
Religion & Christian & 63 & 31.5 \\
& Spiritualist & 16 & 8.0 \\
& Others & 21 & 10.5 \\
\multirow{4}{*}{ Children } & No religion & 4 & 2.0 \\
& No & 12 & 6.0 \\
Monthly income & Yes & 188 & 94.0 \\
per person & Zero & 4 & 2.2 \\
(n=180) & Up to 1 minimum wage & 129 & 71.7 \\
& 1.1 to 3 minimum wages & 39 & 21.7 \\
& 3.1 to 5 minimum wages & 6 & 4.4 \\
\hline
\end{tabular}

Data presented in table 1 demonstrate that the sample was composed predominantly of women within the age category of 50 and 59 years (73\%) with children (94\%). Regarding religion, 48\% were catholic.

Comparing data from table 1 and table 2, the average age of the interviewees was 56.59 years ( \pm 6.60$)$, varying between 50 and 83 years. Among the 188 women who mentioned having children, the average number of children per person was $3.39( \pm 1.91)$. Regarding education, the average number of years of education among the 184 women was 6.37 years $( \pm 3.88)$, varying from one to 20 years. Regarding monthly income per person, $71.7 \%(n=129)$ of the interviewees were observed to receive a monthly income equal to one minimum wage (Table 1).

Table 2 - Sociodemographic characteristics of the subjects in the sample according to mean, standard deviation, median, and minimum and maximum number. São Paulo, 2010 (n=200)

\begin{tabular}{lccccc}
\hline \multicolumn{1}{c}{ Variables } & Mean & Std. deviation & Median & Mín & Máx \\
\hline Age & 56.59 & 6.60 & 55.00 & 50.00 & 83.00 \\
Children $(n=188)$ & 3.39 & 1.91 & 3.00 & 1.00 & 12.00 \\
Education $(n=184)$ & 6.37 & 3.88 & 5.00 & 1.00 & 20.00 \\
\hline
\end{tabular}


Regarding the medical condition of the sub- table 3, as follows.

jects in the sample, findings are demonstrated in

Table 3 - Distribution of the subjects in the sample according to medical characteristics. São Paulo, $2010(n=200)$

\begin{tabular}{|c|c|c|c|}
\hline Medical data & Categories & $\mathbf{n}$ & $\%$ \\
\hline \multirow{2}{*}{ Viral load (last count) } & Undetectable & 142 & 71.0 \\
\hline & More than 50 copies per $\mathrm{ml}$ & 58 & 29.0 \\
\hline \multirow{4}{*}{ CD4 (last count) } & More than $500 / \mathrm{mm}^{3}$ & 107 & 54.0 \\
\hline & From 200-500 & 71 & 35.5 \\
\hline & From $100-200$ & 14 & 7.0 \\
\hline & Less than $100 / \mathrm{mm}$ & 8 & 4.0 \\
\hline \multirow{2}{*}{ Disease classification } & HIV with or without symptoms & 28 & 14.0 \\
\hline & Aids & 172 & 86.0 \\
\hline \multirow{3}{*}{ Use of antiretroviral medication } & No & 26 & 13.0 \\
\hline & Yes & 173 & 86.5 \\
\hline & No record & 1 & 0.5 \\
\hline
\end{tabular}

Table 3 demonstrates that $71 \%$ of the sample have an undetectable viral load; $54.0 \%$ and $35.5 \%$ had a CD4 count higher than $500 / \mathrm{mm}^{3}$ and between $200-500 / \mathrm{mm}^{3}$, respectively; $86.5 \%$ used antiretroviral medications; and $86.0 \%$ were diagnosed with AIDS. and expected variations. São Paulo, $2010(n=200)$

\section{Hope}

HHS components analysis demonstrated a Cronbach's Alpha value of 0.836, demonstrating internal consistency and reliability of the instrument employed in the study.

Table 4 presents the variables composing the HHS according to findings.

Table 4 - Distribution of HHS variables according to mean, standard deviation, median, and obtained

\begin{tabular}{lccccc}
\hline \multicolumn{1}{c}{ Questions } & Mean & Sp* $^{*}$ & Median & $\begin{array}{c}\text { Variations } \\
\text { obtained }\end{array}$ & $\begin{array}{c}\text { Variations } \\
\text { expected }\end{array}$ \\
\hline 1. I feel optimistic about life & 3.08 & 0.67 & 3.0 & $1-4$ & $1-4$ \\
2. I have long-term and short-term plans & 2.83 & 0.68 & 3.0 & $1-4$ & $1-4$ \\
3. I feel very lonely & 2.29 & 0.85 & 2.0 & $1-4$ & $1-4$ \\
4. I can see difficulties within possibilities & 3.05 & 0.57 & 3.0 & $1-4$ & $1-4$ \\
5. I have faith and it comforts me & 3.52 & 0.52 & 4.0 & $2-4$ & $1-4$ \\
6. I fear for my future & 2.69 & 0.72 & 3.0 & $2-4$ & $1-4$ \\
7. I can remember happy and pleasurable moments & 3.18 & 0.58 & 3.0 & $1-4$ & $1-4$ \\
8. I feel very strong & 3.04 & 0.74 & 3.0 & $1-4$ & $1-4$ \\
9. I feel able to give and receive affection/love & 3.32 & 0.53 & 3.0 & $1-4$ & $1-4$ \\
10. I know where I want to go & 2.96 & 0.51 & 3.0 & $2-4$ & $1-4$ \\
11. I believe in the value of each day & 3.33 & 0.54 & 3.0 & $2-4$ & $1-4$ \\
12. I feel my life has value and .usefulness & 3.49 & 0.58 & 4.0 & $2-4$ & $1-4$ \\
\hline Total & $\mathbf{3 6 , 7 5}$ & $\mathbf{4 , 5 3}$ & $\mathbf{3 7 , 0}$ & $\mathbf{2 5 - 4 8}$ & $\mathbf{1 2 - 4 8}$ \\
\hline
\end{tabular}

Sd=Standard deviation.

Data presented in table 4 demonstrate a HHS response index mean score of $36.75( \pm 4.52)$ and median of 37.00 . HHS scores may vary from 12 to 48 and the higher the score, the higher the level of hope. Variations in the total score ranged from 25 to 48 . Also shown in table 4, among the 12 items on the scale, item number three presented a lower mean score (2.29), indicating that $44 \%$ of the sample disagrees with the statement I feel very lonely; however, no total disagreement was present $(39 \%)$. On the other hand, the item presenting the highest mean score was item number 
five (mean of 3.52), demonstrating that $53 \%$ of the subjects agreed with the statement $I$ have faith and it comforts me.

Items 12 I feel that my life has value and is useful, 11 I believe in the value of each day and 9 I feel I am able to give and receive love/affection also deserve highlighting with mean scores of 3.49, 3.33 and 3.32 , respectively.

\section{DISCUSSION}

In this study, findings for the predominant age bracket (50 to 59 years) and the mean age (56.59 years) are congruent with findings in a study performed with women and men with HIV aged between 50 and 59 years in Salvador-BA, which demonstrated an approximate mean age of 53.70 years. ${ }^{14}$ Regarding marital status, most women had no partner, a fact congruent with a study performed in men and women over age 50 with HIV/AIDS in the city of Campinas-SP, where a higher percentage of people were found not to be in a stable union (65.1\%). ${ }^{11}$ In addition, research performed with elderly people with HIV/AIDS in Rio de Janeiro found that $71 \%$ of the subjects were not living in a stable union. ${ }^{15}$

The predominance of Catholic women is congruent with a study where $61.2 \%$ of the subjects also shared this religion. Findings related to education coincide with the social profile of the AIDS epidemic in Brazil, since it affects people having a lower level of education. Regarding monthly income per person, poverty can be observed in this study, which also agrees with the general profile of infected people, where an increase in the proportion by HIV/AIDS among people with a lower income is observed. ${ }^{16-18}$

Having children corroborates another study regarding sexuality and reproductive issues performed with 148 female carriers of HIV who were provided services at a reference center clinic for STI/AIDS located in São Paulo. Most interviewees reported having children. ${ }^{19}$ The average number of children in this present study was 3.39 children. This data was close to the data found in a study performed in Salvador-BA, at the State Reference Center for STI and AIDS, administrated by the Health Department of the State of Bahia, where the average number of children was $2.98 .{ }^{14}$

In this study, most women $(71.0 \%, \mathrm{n}=142)$ presented an undetectable viral load, which is comparable to data in other studies. ${ }^{11,20}$ Viral load demonstrates the number of HIV particles in the blood; the higher its result, the higher the risk is of transmitting the disease. Regarding lymphocytes T-CD4 count, most of the women (53.5\%) presented with values higher than $500 / \mathrm{mm}^{3}$, congruent with another study that observed $45 \%$ of subjects with values higher than $500 / \mathrm{mm}^{3} \cdot{ }^{13}$ However this differs from another research where most subjects presented a CD4 count between 200 and $499 / \mathrm{mm}^{3}{ }^{32}$

Both studies were performed in the state of São Paulo. The first study was performed with 109 subjects aged 50 years or older, HIV/AIDS positive, attending the health complex of the State University of Campinas in the city of Campinas. ${ }^{11}$ The second study was an analytical and co-relational research performed in two AIDS- specialized healthcare services in the city of Ribeirão Preto. ${ }^{20}$

The search for studies which adopted the Herth scale to evaluate levels of hope in carriers of HIV/AIDS demonstrated a lack of research performed on the population segment of interest. Although there are no studies in the national literature which include individuals aged 50 years or older, international publications demonstrate three researches evaluating hope in carriers of HIV/AIDS. ${ }^{21-23}$ Another study had the objective of describing the level of hope in African-American women with HIV/aids and within reproductive age (18 to 45 years), using the Herth Hope Scale and comparing the level of hope of these women to breast cancer patients and hospitalized adult cancer patients. Findings demonstrated the level of hope in women with HIV / AIDS within reproductive age was lower than that of breast cancer patients and hospitalized adult cancer patients. ${ }^{21}$ Another research regarding the correlation of physiologic and psychosocial factors and the perception of health in a sample of 275 women infected with HIV in Georgia, South Carolina and North Carolina used the Herth Hope Index. The women in that study demonstrated a mean score of $38.0( \pm 5.4)$, which is higher than the findings in this present study. ${ }^{22}$

The third study investigates the perception of social support, hope and quality of life in people living with HIV / AIDS in Nepal, using the Hope Scale to evaluate the subjects' level of hope, specifically built for the study. Among the findings, hope was considered a triggering factor for quality of life, since there was a significant association between both. The level of hope reached its apex in the improvement of the quality of life of the population in this study. Only one international study was found using the HHS in women with HIV/ AIDS; 
however, the age bracket evaluated individuals aged 15 to 48 years, not including women aged 50 or above, which is the interest of this study.

A search for national studies using the HHS unearthed only one publication. It was a study performed with oncology patients, diabetics and their companions (family members or caretakers).$^{24}$ In that study, the score obtained from the HHS demonstrated a mean score of $41.57( \pm 4.60)$, $40.46( \pm 4.88)$ and $40.88( \pm 3.77)$ for the cancer patient group, the group of diabetics and their companions, respectively. ${ }^{24}$ These findings demonstrate that women with HIV/AIDS from this present study present lower levels of hope (36.75 \pm 4.52$)$.

International researches employing the HHS, where the subjects presented lower levels of hope compared to the present study although they were not focused on HIV/AIDS, are presented as follows. A study performed with women who received heart transplants investigated hope, their humor condition and quality of life, demonstrating a mean score on the HHS of $35.84( \pm 5.08) .^{25}$ The evaluation of hope and quality of life of people with brain-spinal fluid circulatory disorders in Cambridge (England) found subjects with benign intracranial hypertension had a mean score on the HHS of 35.2; congenital hydrocephaly patients had a mean score of 34.2. ${ }^{26}$

A research that compared the mean obtained on the HHS between oncologic groups with and without pain, and with and without metastasis, demonstrated that people with pain and without metastasis had superior mean scores compared to patients with pain and metastasis; however, all mean scores were above 37.00. In addition, when comparing the cancer patient group experiencing improvement due to treatment $(37.89 \pm 5.13)$ to the group that presented no improvement, the latter presented an inferior mean score $(35.10 \pm 4.92)$. In light of this, only the group of patients who presented no improvement with cancer treatment demonstrated an inferior level of hope compared to this present study with women aged 50 years or older with HIV/ AIDS.

Another investigation regarding the relationship between pain, uncertainty and hope in lung cancer patients in Taiwan demonstrated that the subjects who felt pain presented less hope than those who felt no pain, with mean scores on the HHS of $30.81( \pm 5.95)$ and $36.91( \pm 5.18)$, respectively. ${ }^{28}$

A study of hope in cystic fibrosis patients compared to the general population of Norway demonstrated that individuals with cystic fibrosis had an inferior level of hope compared to the Norwegian population, with mean scores of 36.1 $( \pm 4.1)$ and $37.2( \pm 4.1)$, respectively. ${ }^{29}$

Other relevant data regards the scores obtained for each HHS item. In this present study, item number three (I feel very lonely) from the HHS was the item with the lowest score. In other words, most women with HIV/AIDS disagreed with the statement; however, there was no total disagreement. In seeking other studies with similar mean scores for the same item from the HHS, only two researches were found. They are presented as follows.

A study on hope and pain in hospitalized oncology patients demonstrated the lowest scores on item 6 ("I am afraid for my future") (2.60). ${ }^{30}$ These is similar to the findings in this present study, where the same item yielded low scores. The research regarding hope in patients with cystic fibrosis found that item number 5 ("I have faith and it comforts me") had a lower mean on the HHS, with a score of 2.25. ${ }^{29}$ These findings differed from this present study where women with HIV/AIDS scored the same item with the highest mean score (3.52), confirming their agreement with this item, although their agreement was not total.

Two studies found item number 7 ("I can remember happy and pleasurable moments") with a higher score, with means of $3.61^{29}$ and $3.60 .{ }^{31} \mathrm{In}$ this present study, women with HIV/AIDS had a mean score of 3.18 for the same item. Therefore, although with lower scores, most interviewees in this present research agreed with the statement. However, there was no total agreement.

Other relevant data regard the approach to spirituality and religiosity, since the HHS item which most women aged 50 years or older with HIV/AIDS scored the highest was related to a comforting faith. Religiosity and spirituality concepts must be differentiated: while the latter regards questions about the meaning of life and reason for living, regardless of religious practices, religiosity is understood as the measure of the religion that is accepted, followed and practiced by the individual. The authors of this statement developed a study with individuals with HIV/ AIDS and demonstrated that those who presented higher scores for spiritual welfare tended to be more hopeful. ${ }^{32}$ Other studies also pointed out religiosity and spirituality in people with HIV/ AIDS that may help them face the disease and also promote hope. ${ }^{33-34}$ 


\section{CONCLUSIONS}

In this study, sociodemographic and medical features of the women are congruent with the epidemic profile of carriers of HIV/AIDS in the country. This fact reinforces poverty, heterosexuality and chronic features as characteristics of the disease. Also, it demonstrates that the level of hope presented by women according to the HHS are mostly below the mean scores obtained in other studies approaching chronic and life-threatening diseases published nationally and internationally; the exception can be seen when the same scale is employed for heart transplant, cystic fibrosis and lung cancer patients.

Regarding the statements evaluated by the HHS, most women demonstrated the presence of faith as a support and comfort, in addition to valuing affection, love, daily living and life itself. Hence, faith is an important value in sustaining the hope of these women. Religiosity and spirituality are also important factors raised by the professional in this research, since it is relevant for the care for these people who live with HIV/ AIDS, helping them to cope with the disease and improving their hope and quality of life.

This present study is a professional alert, especially for nurses who care for women aged 50 years or older with HIV/AIDS, to employ active listening in identifying the needs of these women and their families, motivating them to establish goals, contributing to strengthening of social supports and creating interventions with the aim of providing a higher level of hope for these clients.

\section{REFERENCES}

1. Gaspar J, Reis RK, Pereira FMV, Neves LAS, Castrighini CC, Gir E. Qualidade de vida de mulheres vivendo com o HIV/aids de um município do interior paulista. Rev Esc Enferm. USP. 2011 Mar; 45(1):230-6.

2. Valadares ALR, Pinto-Neto AM, Abdo C, Melo VH. HIV em mulheres de meia idade: fatores associados. Rev Assoc Méd Bras. 2010 Jan-Fev; 56(1):112-5.

3. Brasil. Ministério da Saúde. Secretaria de Vigilância em Saúde. Programa Nacional de DST e Aids. Boletim Epidemiológico. Brasília (DF): Ministério da Saúde; n.1, 2011.

4. Bucciardini R, Murri R, Guarnieri M, Starace F, Martini M, Vatrella A et al. ISSQoL: a new questionnaire for evaluation the quality of life of peolple living with in the HAART era. Qual Life Res. 2006 Apr; 15: 377-90.
5. Forbes MA. Hope in the older adult with chronic illness: a comparison of two research methods in theory building. ANS Adv. Nurs. Sci. 1999 Dec; 22(2):74-87.

6. Davison S, Simpson C. Hope and advanced care planning in patients with end stage renal disease: qualitative interview study. BMJ. 2006 Oct; 333(7574): 886-9.

7. Cavaco VSJ, José HMG, Louro SPRLP, Ludgero AFA, Martins AFM, Santos MCG. Qual o papel da esperança na saúde da pessoa? - Revisão sistemática. Referência. 2010 Mar; 12: 93-103.

8. Benzein EG, Berg AC. The Swedish version of Herth Hope Index: an instrument for palliative care. Scand. J. Caring Sci.2003 Dec; 17(4):409-15.

9. Herth K. Abbreviated instrument to measure hope: development and psychometric evaluation. J Adv Nurs. 1992 Oct; 17(10):1251-9.

10. Hulley SB, Cummings SR, Browner WS, Grady DG, Newman TB. Delineando a pesquisa clínica: uma abordagem epidemiológica. $3^{a}$ ed. Porto Alegre: Artmed; 2008.

11. Lima TC. Elaboração, validação e aplicação de um instrumento para caracterização de uma população com 50 anos ou mais portadora do HIV/Aids [dissertação]. Campinas (SP): Universidade Estadual de Campinas, Faculdade de Ciências Médicas; 2009.

12. Sartore AC, Grossi SAA. Escala de Esperança de Herth - instrumento adaptado e validado para a língua portuguesa. Rev Esc Enferm USP. 2008 Jun; 42(2):227-32.

13. Pasquali L. Psicometria: teoria dos testes na psicologia e na educação. Rio de Janeiro: Vozes; 2003.

14. Silva LS, Paiva MS. Vulnerabilidade ao HIV/Aids entre homens e mulheres com mais de 50 anos [online]. In: Anais do VII Congresso Virtual HIV/ Aids, Lisboa, 2006 [acesso 2011 Mai 13]. Disponível em: http://www.aidscongress.net/Modules/ WebC_Docs/GetDocument.aspx?DocumentId=242

15. Zornitta M. Os novos idosos com aids: sexualidade e desigualdade à luz da bioética [dissertação]. Rio de Janeiro: Fundação Oswaldo Cruz; 2008.

16. Braga PE, Cardoso MRA, Segurado AC. Diferenças de gênero ao acolhimento de pessoas vivendo com HIV em serviço universitário de referência de São Paulo, Brasil. Cad Saúde Pública. 2007 Nov; 23(11):2653-62.

17. Paiva V, Latorre MR, Gravato N, Lacerda R. Sexualidade de mulheres vivendo em São Paulo. Cad Saúde Pública. 2002 Nov-Dez; 18(6):1609-20.

18. Nunes CLX, Gonçalves LA, Silva PT, Bina JC. Características clinicoepidemiológicas de um grupo de mulheres com HIV/AIDS em Salvador-Bahia. Rev Soc Bras Med Trop. 2004 Nov-Dez; 37(6):436-40.

19. Santos NJS, Buchalla CM, Fillipe EV, Bugamelli L, Garcia S, Paiva V. Mulheres HIV positivas, 
reprodução e sexualidade. Rev Saúde Pública. 2002 Ago; 36 (Supl4):12-23.

20. Reis RK. Qualidade de vida de portadores do HIV/ Aids: influência dos fatores demográficos, clínicos e psicossociais [tese]. Ribeirão Preto: Universidade de São Paulo, Escola de Enfermagem de Ribeirão Preto; 2008

21. Philips KD, Sowell RL, Misener TR, Tavakoli A. Levels of hope in HIV-infected African-American women of reproductive age. Clin Excell Nurse Pract. 2000 Mar; 4(2):90-7.

22. Phillips KD, Sowell RL, Rush C, Murdaugh C. Psychosocial and physiologic correlates of perceived health among HIV-infected women. Southern Online J Nurs Res [online]. 2001 Jan [acesso 2001 Jun 22]; 3(2):1-25. Disponível em: http://www. resourcenter.net/images/SNRS/Files/SOJNR_ articles/iss03vol02.pdf

23. Yadav S. Perceived social support, hope, and quality of life of persons living with HIV/AIDS: a case study from Nepal. Qual Life Res. 2010 Mar; 19, 157-66.

24. Balsanelli ACS, Grossi SAA, Herth KA. Cultural adaptation and validation of the herth Hope Index for portuguese language: study in patients with chronic illness. Texto Contexto Enferm. 2010 OutNov; 19(4):754-61.

25. Evangelista LS, Doering LD, Dracup K, Vassilakis ME, Kobashigawa J. Hope, mood states and quality of life in female heart transplant recipients. J Heart Lung Transplant. 2003 Jun; 22(6):681-6.

26. Gelling L, Iddon J, McVicar A, Pickard JD. CSF circulation disorders: measuring progress in patients through quality of life and hope. J Clin Nurs. 2004 Jul; 13:589-600.

27. Chen ML. Pain and Hope in patients with cancer: a role for cognition. Cancer Nursing. 2003 Jun; 26(1):61-7.

28. Hsu T, Lu MS, Tsou TS, Lin CC. The relationship of pain, uncertainty, and hope in Taiwanese lung cancer patients. J Pain Symptom Manage. 2003 Sep; 23(3):835-42.

29. Rustoen T, Wahl AK, Hanestad BR, Lerdal A, Miaskowski C, Moum T. Hope in the general Norwegian population, measured using the Herth Hope Index. Palliat Support Care. 2003 Dec; 1, 309-318.

30. Utne I, Miaskowski C, Bjordal K, Paul SM, Jakobsen G, Rustoen T. The relationship between hope and pain in a sample of hospitalized oncology patients. Palliat Support Care. 2008 Dec; 6, 327-34.

31. Vitale A, Genge A. Codman Award 2006: the experience of hope in ALS patients. Axone. 2007 Winter; 28(2):27-35.

32. Fleck MPA, Borges ZN, Bolognesi G, Rocha NS. Desenvolvimento do WHOQOL, módulo espiritualidade, religiosidade e crenças pessoais. Rev Saúde Pública. 2003 Ago; 37(4): 446-55.

33. Newshan G. Transcending the physical: spiritual aspects of pain in patients with HIV and/or cancer. J Adv Nurs. 1998 Dec; 28:1236-41.

34. Prado G, Feaster DJ, Schwartz SJ, Pratt IA, Smith L, Szapocznik J. Religious involvement, coping, social support, and psychological distress in HIV - soropositive African American mothers. AIDS Behav. 2004 Sep; 8(3):221-35. 